\title{
ARBUSCULAR MYCORRHIZA OF PLANTS SPONTANEOUSLY COLONIZING THE SODA HEAP IN JAWORZNO (SOUTHERN POLAND)
}

\author{
EWA GUCWA-PRZEPIÓRA ${ }^{1}$, JANUSZ BŁASZKOWSKI ${ }^{2}$ \\ ${ }^{1}$ Department of Plant Systematics, University of Silesia \\ Jagiellońska 28, 40-032 Katowice, Poland \\ e-mail: egucwa@us.edu.pl \\ 2 Department of Plant Pathology, University of Agriculture \\ Słowackiego 17, 71-434 Szczecin, Poland
}

(Received: March 20, 2006. Accepted: July 3, 2006)

\begin{abstract}
The results of studies of the mycorrhizal status of plant species spontaneously established on the soda heap located in Jaworzno (Upper Silesia, Poland) are presented. Additionally, the species of arbuscular fungi of the phylum Glomeromycota extracted from field-collected rhizosphere substrate samples of the heap are showed. Arbuscular mycorrhizae were described in 17 plant species. Five Glomus spp. were recognized in the spore populations of arbuscular fungi isolated. The investigation presented in this paper for the first time revealed Centaurea stoebe and Trifolium montanum to be hosts of arbuscular fungi.
\end{abstract}

KEY WORDS: arbuscular mycorrhiza, industrial wastes, soda heap, Glomeromycota.

\section{INTRODUCTION}

Massive destruction of native vegetation occur throughout the world because of the industrial land use by people. Top soil removal and piling up heaps usually highly reduce the occurrence and activity of soil microorganisms beneficial for plants, among which are arbuscular mycorrhizal fungi (AMF) of the phylum Glomeromycota (Jasper et al. 1987; Rives et al. 1980; Stahl et al. 1988; Bellgard 1993) suggested to co-exist in an obligate symbiosis with at least $80 \%$ of all plants of the world (Gianinnazzi and Gianinazzi-Pearson 1986).

Arbuscular mycorrhizae (AM) alleviate many anthropogenic stresses, including those caused by heavy metals and toxic inorganic and organic substances deposited in the so$\mathrm{il}$, as well as those resulting from too high compaction and pH of soil (Schüepp et al. 1987; Gildon and Tinker 1983; Weissenhorn et al. 1995; Entry et al. 2002). Additionally, AMF improve natural succession of plants in habitats where their colonization is slow, e.g., on sand dunes (Sylvia and Will 1988; Corkidi and Rincon 1997a, b) and contaminated areas such as industrial wastes (Khan 1978; Hetrick et al. 1994; Gucwa-Przepióra and Turnau 2001).

Many post-industrial sites have been recognized as refuges for protected and rare plant species, including the soda heap at Jaworzno (Upper Silesia, Poland; Cohn et al. 2001). Thus, considering the positive results of the cooccurrence of plants and AMF presented above, the reco- gnition of the mycorrhizal status of plants and associated AMF in such sites may be helpful in the elaboration of strategies of protection of these associations by e.g., introduction of species of AMF best adapted to particular local conditions.

The main aim of the study presented here was to assess the mycorrhizal colonization of selected herbaceous plants spontaneously established in an old solvay process heap in Jaworzno. Additionally, this paper shows species of the mycorrhizal fungi extracted from field-collected substrate samples of the heap.

\section{MATERIALS AND METHODS}

\section{Site description}

The study area was located in Jaworzno-Szczakowa, which lies in the Jaworzno Hills in the Silesian Upland $\left(50^{\circ} 18^{\prime} \mathrm{N} ; 19^{\circ} 10^{\prime} \mathrm{E}\right)$. The heap is situated close to the Szczakowa window glass factory and Katowice-Cracow railway tracks. The site occupies ca. 2 ha and is isolated on all sides by steep, more or less bare, vertical eroded banks, ca. 3 $\mathrm{m}$ high (Fig. 1). It is an abandoned solvay process slurry heap from a former Austrian soda factory, which produced soda until 1911. Thus, the present day heap probably represents the place where calcium chloride was deposited.

The vegetation of the study area mainly consisted of species characteristic for meadows and grasslands. Additio- 

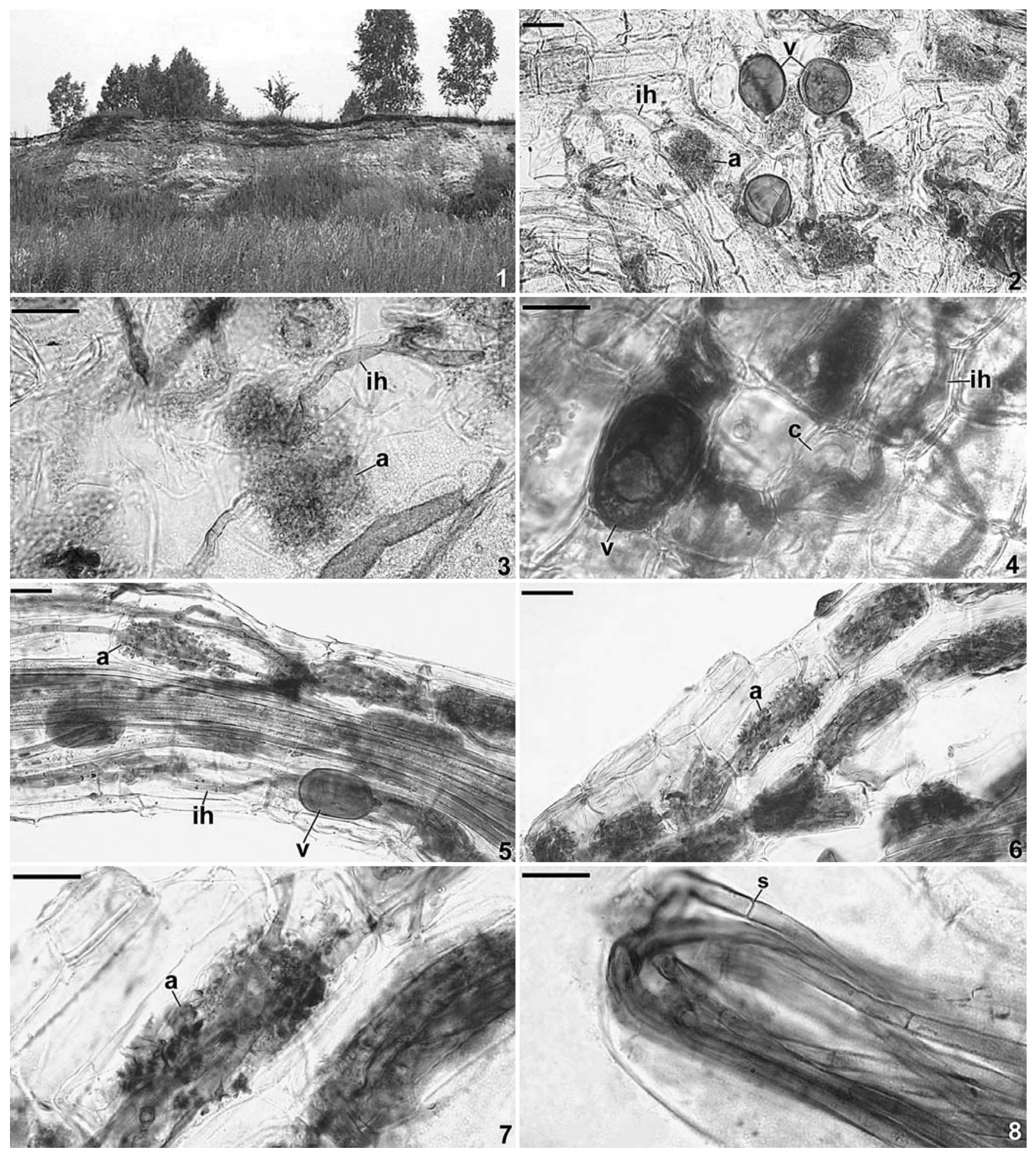

Fig. 1. General view of the solvay process heap in Jaworzno. Figs 2 and 3. Arbuscules (a), vesicles (v), and intraradical hyphae (ih) in roots of Centaurea stoebe. Fig. 4. Vesicle and coil in a root of Tofieldia calyculata. Figs 5-7. Arbuscules (a), vesicles (v), and intraradical hyphae (ih) in roots of Trifolium montanum. Fig. 8. Coil in a root of Epipactis atrorubens; septum (s) is indicated. Bars: Figs 2, 5, and 6=20 um; Figs 3, 7, and 8=10 $\mu \mathrm{m}$.

nally, birch trees and shrubs occasionally occurred there. The site is shown to be an important refuge for some protected and mountain species, and other elements uncommon in the local flora (Cohn et al. 2001).

\section{Substrate}

The solvay process produced "white seas" of calcium chloride as an aqueous suspension, so the site is the place where it was probably deposited. Previous investigations showed that the external layer of the heap consists of slag and soil mixture (unpublished material gathered by the existing window glass factory Szczakowa SA). The deeper layer contains lime waste with a significant proportion of magnesium and a low level of chloride ions.

Properties of the substrate were analyzed as follows: total $\mathrm{N}$ was determined with the Kjeldahl method, organic $\mathrm{C}$ with the Tiurin method, available $\mathrm{P}$ with the EgnerRhiem method, $\mathrm{pH}$ and $\mathrm{EC}$ were measured in water extract with combination glass/calomel electrode and $\mathrm{pH}$ meter. General properties and the concentration of elements of the 
TABLE 1. General properties of the Jaworzno soda heap substrate.

\begin{tabular}{lc}
\hline $\mathrm{pH}\left(\mathrm{H}_{2} \mathrm{O}\right)$ & 7.7 \\
$\mathrm{~N}$ total $\left[\mathrm{g} \mathrm{kg}^{-1}\right.$ air d.w.] & 4.06 \\
$\mathrm{C}$ organic $\left[\mathrm{g} \mathrm{kg}^{-1}\right.$ air d.w.] & 87.14 \\
$\mathrm{P}$ available $\left[\mathrm{mg} \mathrm{kg}^{-1}\right.$ air d.w.] & 8.38 \\
$\mathrm{C}: \mathrm{N}$ & 22.33 \\
$\mathrm{EC}[\mu \mathrm{S} / \mathrm{cm}]$ & 351.5 \\
\hline
\end{tabular}

TABLE 2. Concentration of elements in the substrate. Values represent range of elements concentration as percentage of sieved, dry soil (X-Ray Fluorescence Spectrometry) (Cohn et al. 2001).

\begin{tabular}{cc}
\hline $\mathrm{Al}$ & $4.59-8.85$ \\
$\mathrm{Ba}$ & $0.034-0.081$ \\
$\mathrm{Ca}$ & $24.19-39.47$ \\
$\mathrm{Cl}$ & $0.12-0.27$ \\
$\mathrm{Cu}$ & $0.003-0.006$ \\
$\mathrm{Fe}$ & $2.20-5.71$ \\
$\mathrm{~K}$ & $0.41-0.95$ \\
$\mathrm{Mg}$ & $0.59-2.09$ \\
$\mathrm{Mn}$ & $0.034-0.75$ \\
$\mathrm{Na}$ & $0.25-0.34$ \\
$\mathrm{P}$ & $0.16-0.21$ \\
$\mathrm{~Pb}$ & $0.21-0.036$ \\
$\mathrm{~S}$ & $0.23-0.40$ \\
$\mathrm{Si}$ & $17.41-29.32$ \\
$\mathrm{Ti}$ & $0.15-0.39$ \\
$\mathrm{Zn}$ & $0.10-0.20$ \\
\hline
\end{tabular}

Jaworzno soda heap rhizosphere substrate are listed in Table 1 and Table 2 .

Sampling of plants, roots, and assessment of AM colonization

Specimens of twenty common herbaceous plant species spontaneously established in the Jaworzno soda heap were collected in July 2004. Latin names of the plants follow Mirek et al. 2002. The plant specimens were deposited in the herbarium of the University of Silesia (KTU).

To evaluate AM colonization, root samples of at least five flowering plants of each species were collected from a depth of 0-20 cm. After their transfer to a laboratory, the roots were first washed out in tap water, then cut into 1.0-cm-long segments, softened in $7 \% \mathrm{KOH}$ at $60^{\circ} \mathrm{C}$ for $1 \mathrm{~h}$, rinsed in a few changes of water, acidified in 5\% lactic acid at room temperature for 1-24 h, and finally stained with $0.01 \%$ aniline blue in $5 \%$ lactic acid at $60^{\circ} \mathrm{C}$ for $0.5 \mathrm{~h}$. The stained root segments were stored in lactoglycerol until they were used for slide preparation.

Mycorrhizal colonization of the plant species sampled was assessed following the calculation of mycorrhizal frequency $(\mathrm{F} \%)$, intensity of root cortex colonization (M\%), and arbuscule abundance (A\%) according to the method described by Trouvelot et al. (1986; http://www.dijon.inra.fr/mychintec/Mycocalc-prg/download.html).

\section{Collection of rhizosphere substrates,} isolation and identification of AMF

To determine species of arbuscular fungi occurring in the heap examined, during flowering of its most plants in July
2005, rhizosphere substrate were collected in 3 randomly selected sites from a depth of 5-20 cm using a small garden shovel. About $500 \mathrm{~cm}^{3}$ samples were placed in plastic bags. In the laboratory, they were first air dried and then stored at $4^{\circ} \mathrm{C}$ for ca. one month until processing.

Spores of AMF were extracted by wet sieving and decanting (Gerdemann and Nicolson 1963). Morphological properties of spores and their subcellular structures were determined based on at least 30 spores mounted in polyvinyl alcohol/lactic acid/glycerol (PVLG; Omar et al. 1979) and a mixture of PVLG and Melzer's reagent $(1: 1, \mathrm{v} / \mathrm{v})$. Spores were crushed to varying degrees by applying pressure to the cover slip and then stored at $65^{\circ} \mathrm{C}$ for $24 \mathrm{~h}$ to clear their contents from oil droplets. These were examined under an Olympus BX 50 compound microscope equipped with Nomarski differential interference contrast optics. Microphotographs were recorded on a Sony 3CDD color video camera coupled to the microscope. Vouchers of all the fungal species recovered are preserved in the authors' collections. Colour microphotographs of spores and mycorrhizae of the AM fungal species found can be viewed at the URL http://www.agro.ar.szczecin.pl/ jblaszkowski/.

\section{RESULTS}

The mycorrhizal status of vegetation of the soda heap in Jaworzno was determined based on root samples of 20 species belonging to 12 plant families. Arbuscular mycorrhizae were found in 17 plant species. The mycorrhizal structures of all the plant species found to host arbuscular fungi comprised arbuscules, and vesicles (Table 3; Figs 2, 3 and 5-7), with the exception of Anthyllis vulneraria, which mycorrhizal roots did not contain vesicles as well as coils (Table 3). Coils were present among arbuscular mycorrhizae of 8 plant species. Few coils and vesicles also occurred in roots of Tofieldia calyculata, although no arbuscules accompanied them (Table 3, Fig. 4)

Except for Euphrasia stricta having a relatively low AM frequency, the average frequencies of AM colonization in the other plant species ranged from 80 to $100 \%$ (Table 3).

In 13 plant species, more than $50 \%$ of their root cortex was colonized by AMF (Table 3). The intensity of root cortex colonization $(\mathrm{M} \%)$ in the other four plant species was mean and ranged from $15.7 \%$ (Euphrasia stricta) to 45.5\% (Dianthus carthusianorum).

The arbuscule abundance (A\%) exceeded $50 \%$ in Achillea millefolia, Molinia coerulea, Plantago media, and Prunella vulgaris (Table 3). In 12 plant species, it was within the $10-50 \%$ range. Low relative arbuscular richness was found only in Euphrasia stricta (4.1\%).

In the field-collected substrate samples, a total of five species of AMF were identified. All represented the genus Glomus. Only spores of G. fasciculatum and G. mosseae were not numerous ( $<50$ spores in $100 \mathrm{~g}$ dry soil). The spore abundance of the other species was high (50-100 spores in $100 \mathrm{~g}$ dry soil; G. macrocarpum) to very high (>100 spores in $100 \mathrm{~g}$ dry soil; G. constrictum and G. microcarpum).

Mycorrhizal status of two representatives of the family Orchidaceae: Epipactis atrorubens and Epipactis palustris were also examined, but only the former one harboured orchid mycorrhizae (Fig. 8). 
TABLE 3. AM structures and AM colonization of plants from the soda heap in Jaworzno (values listed as means \pm standard errors).

\begin{tabular}{|c|c|c|c|c|c|c|}
\hline \multirow{2}{*}{ Plant species } & \multicolumn{3}{|c|}{ AM structures } & \multicolumn{3}{|c|}{ AM colonization } \\
\hline & A & V & $\mathrm{C}$ & $\mathrm{F} \%$ & $\mathrm{M} \%$ & $\mathrm{~A} \%$ \\
\hline Achillea millefolium & + & + & - & $100 \pm 0$ & $87.3 \pm 5.4$ & $80.0 \pm 3.3$ \\
\hline Anthyllis vulneraria & + & - & - & $100 \pm 0$ & $70.2 \pm 3.8$ & $36.0 \pm 4.5$ \\
\hline Asperula cynanchica & + & + & + & $100 \pm 0$ & $57.3 \pm 4.1$ & $46.5 \pm 6.0$ \\
\hline Briza media & + & + & + & $100 \pm 0$ & $74.7 \pm 3.9$ & $43.7 \pm 4.3$ \\
\hline Calamagrostis epigeios & + & + & - & $100 \pm 0$ & $44.1 \pm 6.3$ & $27.9 \pm 4.4$ \\
\hline Carlina vulgaris & + & + & - & $100 \pm 0$ & $83.0 \pm 2.8$ & $45.3 \pm 3.8$ \\
\hline Centhaurea stoebe & + & + & + & $100 \pm 0$ & $90.0 \pm 4.9$ & $40.0 \pm 5.2$ \\
\hline Dianthus carthusianorum & + & + & + & $80.0 \pm 2.1$ & $45.5 \pm 7.3$ & $23.2 \pm 3.8$ \\
\hline Euphrasia stricta & + & + & - & $26.7 \pm 3.5$ & $15.7 \pm 6.8$ & $4.1 \pm 1.7$ \\
\hline Inula salicina & + & + & + & $100 \pm 0$ & $56.3 \pm 3.2$ & $29.7 \pm 2.4$ \\
\hline Molinia coerulea & + & + & + & $100 \pm 0$ & $74.7 \pm 4.4$ & $58.5 \pm 4.0$ \\
\hline Plantago media & + & + & + & $100 \pm 0$ & $72.1 \pm 3.4$ & $53.2 \pm 3.7$ \\
\hline Prunella vulgaris & + & + & - & $100 \pm 0$ & $85.6 \pm 2.8$ & $51.3 \pm 2.2$ \\
\hline Scabiosa ochroleuca & + & + & + & $100 \pm 0$ & $81.3 \pm 6.6$ & $42.1 \pm 5.3$ \\
\hline Thymus pulegioides & + & + & - & $100 \pm 0$ & $86.3 \pm 4.1$ & $27.4 \pm 4.3$ \\
\hline Tofieldia calyculata & - & + & + & 0.0 & 0.0 & 0.0 \\
\hline Trifolium montanum & + & + & - & $100 \pm 0$ & $69.3 \pm 5.7$ & $43.6 \pm 1.8$ \\
\hline Valeriana officinalis & + & + & - & $93.3 \pm 3.3$ & $23.3 \pm 4.8$ & $17.5 \pm 5.7$ \\
\hline
\end{tabular}

Abbreviations:

AM - arbuscular mycorrhiza; A - arbuscules; V - vesicles; C - coils;

$\mathrm{F} \%$ - mycorrhizal frequency; M\% - intensity of root cortex colonization;

A\% - arbuscule abundance

\section{DISCUSSION}

The investigations of the mycorrhizal status of 20 plant species established on the soda heap in Jaworzno showed that $85 \%$ of them were associated with AMF of the phylum Glomeromycota. A similar proportion of plants with arbuscular mycorrhizae in the total number of plants examined was found by, e.g., Dodd et al. (2002) in a chalk marl reclamation platform created by the tunnelling of the Cannel Tunnel Railing in UK and by Pawłowska (1991) in a 32year-old sedimentation basin with wastes from a soda factory. This confirms conclusions of many studies that AMF may tolerate very high $\mathrm{pH}$ and harmful concentrations of different soil chemical elements (e.g., Oliviera et al. 2005; Pawłowska 1991; Pawłowska et al. 1996; Turnau et al. 2001).

Of the plant species potentially able to associate with AMF, only roots of Tofieldia calyculata (Liliaceae) did not contain arbuscules (Table 3), although they hosted few coils and vesicles (Fig. 4) highly resembling those formed by fungi of the Glomeromycota. Arbuscules are the most important exponents of active arbuscular mycorrhizae (Smith and Read 1997). All investigations of the mycorrhizal status of Tofieldia calyculata so far performed in Poland showed this plant to not associate with AMF (Dominik and Nespiak 1953; Dominik et al. 1954a, b; Dominik and Pachlewski 1956; Nespiak 1953; Zubek et al. 2005). However, most of the three-quarters of the British species of the Liliaceae examined developed vesicular-arbuscular mycorrhizae, including a member of the genus Tofieldia (Harley and Harley 1987). Tofieldia calyculata is a species characteristic of calcareous fens of the Caricion davallianae Klika 1934 alliance (Matuszkiewicz 2001). Thus, both the Jaworzno soda heap and the other Polish sites in which the mycorrhizae of this plant were examined (see above) were untypical for it. The real mycorrhizal status of Tofieldia calyculata existing in the conditions of the Jaworzno soda heap may reveal (1) studies of roots of this plant in different periods of vegetation, (2) cultivation of Tofieldia calyculata in pot cultures with its field-collected rhizosphere soils to initiate sporulation of associated AMF (Błaszkowski et al. 2002; Stutz and Morton 1996), and the use of specific DNA primers exhibiting AMF hidden in roots of this plant (Kubota et al. 2005; Turnau et al. 2001).

The finding of arbuscular mycorrhizae in Centaurea stoebe and Trifolium montanum by the authors of this paper (Figs 2, 3, and 5-7) is the first report of the mycorrhizal status of these plant species.

Of the two Epipactis spp. examined, i.e., Epipactis atrorubens and Epipactis palustris, only the former harboured orchid mycorrhizae (Fig. 8), as e.g. Harley and Harley (1987) showed in Great Britain and Pawłowska (1991) when this plant grew in the Cracow (Poland) soda factory wastes. According to Harley and Harley (1987), all the species of the British flora investigated formed orchid mycorrhizae, including Epipactis palustris.

The presence of arbuscules in all plant species recognized to associate with AMF (Table 3) indicates that this symbiosis functioned in the soil conditions highly injurious for plants. Arbuscules are the main structures of exchange of nutrients between the two partners of this type of mycorrhizae (Smith and Read 1997). Another evidence of functioning of mycorrhizae in the conditions of the Jaworzno soda heap was the frequent occurrence of coils among the mycorrhizal structures revealed. Apart from arbuscules, coils may also serve as sites of carbon acquisition by the fungus and phosphorous efflux to the host plant (Smith and Smith 1996). 
The species diversity of the spore populations extracted from field-collected substrate samples of the Jaworzno heap was relatively low and was limited to only five species of the genus Glomus. A similar species richness was found in many other studies involving heavy-metal polluted sites (Pawłowska et al. 1996), soils highly acidified and salted (Turnau et al. 2001), and other severely degraded and polluted ecosystems (e.g., Vosatka and Dodd 2002). Constrains in AMF community structure to only Glomus spp. have earlier frequently been observed in contaminated soils (Oliviera et al. 2005; Vosatka and Dodd 2002). However, many species of AMF sporulate seasonally or rarely in the field (Błaszkowski et al. 2002; Stutz and Morton 1996). Therefore, the recognition of the full species composition of AMF associated with plants of the Jaworzno soda heap will need to cultivate their rhizosphere soils in successive trap cultures and gradual extraction of spores of appearing fungi. Stutz and Morton (1996) showed that $75 \%$ of the species found after three culture cycles were not detected in the first trap culture. Nevertheless, as Turnau et al. (2001) suggested, the sporulation of the five Glomus spp. in the arduous site examined by the authors of this paper may indicate that only these quickly adapted to exist. Glomus constrictum, G. fasciculatum, G. macrocarpum, G. microcarpum, and $G$. mosseae occur in all regions of the world (Błaszkowski 2003). According to Stahl and Christensen (1982), a wide distribution of some species of AMF results from easiness of their genetic adaptation to different environmental conditions. Read (2002) concluded that disturbance, although causes looses of genetic diversity, also leads to selection of distinctive genotypes specially adapted to particular conditions.

\section{ACKNOWLEDGMENTS}

This study was supported in part by The Committee of Scientific Researches, grant no. 2 P04C 04128.

\section{LITERATURE CITED}

BELLGARD S.E. 1993. The topsoil as the major store of propagules of vesicular-arbuscular mycorrhizal fungi in south-east Australian sandstone soils. Mycorrhiza 3: 19-24.

BŁASZKOWSKI J. 2003. Arbuscular mycorrhizal fungi (Glomeromycota), Endogone, and Complexipes species deposited in the Department of Plant Pathology, University of Agriculture in Szczecin, Poland. http://www.agro.ar.szczecin.pl/ jblaszkowski/.

BŁASZKOWSKI J., TADYCH M., MADEJ T. 2002. Arbuscular mycorrhizal fungi (Glomales, Zygomycota) of the Błędowska Desert. Acta Soc. Bot. Pol. 71: 71-85.

COHN E.V.J., ROSTAŃSKI A., TOKARSKA-GUZIK B., TRUEMAN I.C., WOŹNIAK G. 2001. The flora and vegetation of an old Solvay process tip in Jaworzno (Upper Silesia, Poland). Acta Soc. Bot. Pol. 70: 47-60.

CORKIDI L., RINCON E. 1997a. Arbuscular mycorrhizae in a tropical sand dune ecosystem on the Gulf of Mexico: I. Mycorrhizal status and inoculum potential along a successional gradient. Mycorrhiza 7: 9-15.

CORKIDI L., RINCON E. 1997b. Arbuscular mycorrhizae in a tropical sand dune ecosystem on the Gulf of Mexico: II. Effects of arbuscular mycorrhizal fungi on the growth of species distributed in different early successional stages. Mycorrhiza 7: 17-23.
DODD J.C., DOUGALL T.A., CLAPP J.P., JEFFRIES P. 2002. The role of arbuscular mycorrhizal fungi in plant community establishment at Samphire Hoe, Kent, UK - the reclamation platform created during the building of the Channel tunnel between France and the UK. Biodivers. Conserv. 11: 39-58.

DOMINIK T., NESPIAK A. 1953. Badanie mykotrofizmu zespołów roślinnych krainy kosodrzewu w granitowych Tatrach. Acta Soc. Bot. Pol. 22: 753-769. (in Polish)

DOMINIK T., NESPIAK A., PACHLEWSKI R. 1954a. Badanie mykotrofizmu roślinności zespołów na skałkach wapiennych w Tatrach. Acta Soc. Bot. Pol. 23: 471-485. (in Polish)

DOMINIK T., NESPIAK A., PACHLEWSKI R. 1954b. Badanie mykotrofizmu zespołów roślinnych regla górnego w Tatrach. Acta Soc. Bot. Pol. 23: 487-504. (in Polish)

DOMINIK T., PACHLEWSKI R. 1956. Badanie mykotrofizmu zespołów roślinnych regla dolnego w Tatrach. Acta Soc. Bot. Pol. 25: 3-26. (in Polish)

ENTRY J.A., RYGLEWICZ P.T., WATRUD L.S., DONNELLY P.K. 2002. Influence of adverse soil conditions on the formation and function of arbuscular mycorrhizas. Adv. Environ. Res. 7: 123-138.

GERDEMANN J.W., NICOLSON T.H. 1963. Spores of mycorrhizal Endogone species extracted from soil by wet sieving and decanting. Trans. Br. Mycol. Soc. 46: 235-244.

GIANINAZZI S., GIANINAZZI-PEARSON V. 1986. Progress and headaches in endomycorrhiza biotechnology. Symbiosis 2, 139-149.

GILDON A., TINKER P.B. 1983. Interactions of vesicular-arbuscular mycorrhizal infections and heavy metals in plants. I. The effects of heavy metals on developement of vesicular-arbuscular mycorrhizas. New Phytol. 95: 247-261.

GUCWA-PRZEPIÓRA E., TURNAU K. 2001. Arbuscular mycorrhiza and plant succession on zinc smelter spoil heap in Katowice-Wełnowiec. Acta Soc. Bot. Pol 70: 153-158.

HARLEY J.L., HARLEY E.L. 1987. A check-list of mycorrhiza in the British flora. New Phytol. 105: 1-102.

HETRICK B.A.D., WILSON G.W.T., FIGGE D.A.H. 1994. The influence of mycorrhizal symbiosis and fertilizer amendments on establishment of vegetation in heavy metals mine spoil. Environ. Pollut. 86: 171-179.

JASPER D.A., ROBSON A.D., ABBOTT L.K. 1987. The effect of surface mining on the infectivity of vesicular-arbuscular mycorrhizal fungi. Austral. J. Bot. 35: 641-652.

KHAN A.G. 1978. Vesicular-arbuscular mycorrhiza in plants colonizing black wastes from bituminous coal mining in the Illawarra region of New South Wales. New Phytol. 81: 53-63.

KUBOTA M., McGONIGLE T.P., HYAKUMACHI M. 2005. Co-occurrence of Arum- and Paris-type morphologies of arbuscular mycorrhizae in cucumber and tomato. Mycorrhiza 15: 73-77.

MATUSZKIEWICZ W. 2001. Przewodnik do oznaczania zbiorowisk roślinnych Polski. PWN, Warszawa, pp. 536. (in Polish)

MIREK Z., PIĘKOŚ-MIRKOWA H., ZAJĄC A., ZAJĄC M. 2002. Flowering plants and pteridophytes of Poland. A checklist. W. Szafer Institute of Botany, Polish Academy of Science, Kraków, pp. 442.

NESPIAK A. 1953. Badania mikotrofizmu roślinności alpejskiej ponad granicą kosodrzewiny w granitowych Tatrach. Acta Soc. Bot. Pol. 22: 97-125. (in Polish)

OLIVIERA R.S., VOSÁTKA M., DODD J.C., CASTRO P.M.L. 2005. Studies on the diversity of arbuscular mycorrhizal fungi and the efficacy of two native isolates in a highly alkaline anthropogenic sediment. Mycorrhiza 16: 23-31.

OMAR M.B., BOLLAN L., HEATHER W.A. 1979. A permanent mounting medium for fungi. Bull. Br. Mycol. Soc. 13: 31-32.

PAWŁOWSKA T.E. 1991. Plant mycorrhizae in the sedimentation tanks of the Cracow soda factory. Zesz. Nauk. Uniw. Jagiell. Pr. Bot. 22: 163-170. 
PAWŁOWSKA T.E., BŁASZKOWSKI J., RÜHLING Å. 1996. The mycorrhizal status of plants colonizing a calamine spoil mound in southern Poland. Mycorrhiza 6: 499-505.

READ D.J. 2002. An ecological point of view on arbuscular mycorrhiza research. In: Mycorrhizal technology in Agriculture. From genes to Bioproducts. Gianinazzi S., Schüepp H., Barea J.M., Haselwandter K. (eds). Birkhäuser, Basel, pp. 129-136.

RIVES C.S., BAJWA M.I., LIBERTA A.E., MILLER R.M. 1980. Effects of topsoil storage during surface mining on the viability of Virginia mycorrhiza. Soil Science. 129: 253-257.

SCHÜEPP H., DEHN B., STICHER H. 1987. Interaktionen zwischen VA-Mycorrhizen und Schwermetallbelastungen. Angew. Botanik 61: 85-96.

SMITH F.A., SMITH S.E. 1996. Mutualism and parasitism: biodiversity in function and structure in the "arbuscular" (VA) mycorrhizal symbiosis. Adv. Bot. Res. 22: 1-43.

SMITH S.E., READ D.J. 1997. Mycorhizal symbiosis. Academic Press. Harcourt Brace \& Company, Publishers. San Diego, London, New York, Boston, Sydney, Tokyo, Toronto, pp. 605.

STAHL P.D., CHRISTENSEN M. 1982. Mycorrhizal fungi associated with Bouteloua and Agropyron in Wyoming sagebrushgrasslands. Mycologia 74: 877-885.

STAHL P.D., WILLIAMS S.E., CHRISTENSEN M. 1988. Efficacy of native vesicular-arbuscular mycorrhizal fungi in drastically disturbed soil. New Phytol. 110: 347-354.

STUTZ J.C., MORTON J.B. 1996. Successive pot cultures reveal high species richness of arbuscular mycorrhizal fungi in arid ecosystems. Can. J. Bot. 74: 1883-1889.
SYLVIA D.M., WILL M.E. 1988. Establishment of VA mycorrhizal fungi and other microorganisms on a beach replenishment site in Florida. Appl. Environ. Microbiol. 54: 348-352.

TROUVELOT A., KOUGH J.L., GIANINAZZI-PEARSON V. 1986. Mesure du taux de mycorhization VA d'un systéme radiculaire. Recherche de méthodes d'estimationayant une signification fonctionelle. In: Physiological and genetical aspects of mycorrhizae. Gianinazzi-Pearson V., Gianinazzi S. (eds). Paris, INRA, pp. 217-221.

TURNAU K., RYSZKA P., GIANINAZZI-PEARSON V., VAN TUINEN D. 2001. Identification of arbuscular mycorrhizal fungi in soils and roots of plants colonizing zinc wastes in southern Poland. Mycorrhiza 10: 169-14.

VOSÁTKA M., DODD J.C. 2002. Ecological coniderations for successful aplication of arbuscular mycorrhizal fungi inoculum. In: Mycorrhizal technology in agriculture. Gianinazzi S., Schuepp H., Barea J. M., Haselwandter K. (eds). Birkhauser, Basel, pp. 235-247.

WEISSENHORN I., LEYVAL C., BELGY G., BERTHELIN J. 1995. Arbuscular mycorrhizal contribution of heavy metal uptake by maize (Zea mays L.) in pot culture with contaminated soil. Mycorrhiza 5: 245-251.

ZUBEK S., TURNAU K., BŁASZKOWSKI J. 2005. Arbuscular mycorrhiza of plants from the Mountain Botanical Garden in Zakopane. Acta Mycol. 40: 25-41. 